\title{
Reactive astrogliosis in the dentate gyrus of mice exposed to active volcanic environments
}

\author{
A. Navarro , M. García , A.S. Rodrigues , P.V. Garcia , R. Camarinho \& Y. \\ Segovia
}

To cite this article: A. Navarro , M. García , A.S. Rodrigues, P.V. Garcia , R. Camarinho \& Y. Segovia (2021) Reactive astrogliosis in the dentate gyrus of mice exposed to active volcanic environments, Journal of Toxicology and Environmental Health, Part A, 84:5, 213-226, DOI: $10.1080 / 15287394.2020 .1850381$

To link to this article: https://doi.org/10.1080/15287394.2020.1850381

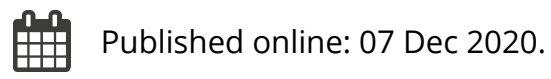

Submit your article to this journal $\sqsubset$

Џll Article views: 40

Q View related articles $\longleftarrow$

View Crossmark data $₫$ 


\title{
Reactive astrogliosis in the dentate gyrus of mice exposed to active volcanic environments
}

\author{
A. Navarro ${ }^{a}$, M. García ${ }^{a}$ A.S. Rodrigues ${ }^{b, c}$, P.V. Garcia ${ }^{b, d}$, R. Camarinho $o^{b, c}$, and Y. Segovia ${ }^{a}$ \\ aDepartment of Biotechnology, University of Alicante, Alicante, Spain; ${ }^{b}$ Faculty of Sciences and Technology, University of the Azores, Ponta \\ Delgada, Portugal; ‘VAR, Research Institute for Volcanology and Risk Assessment, University of the Azores, Ponta Delgada, Portugal; dcE3c, \\ Centre for Ecology, Evolution and Environmental Changes, and Azorean Biodiversity Group, University of the Azores, Ponta Delgada, Portugal
}

\begin{abstract}
Air pollution has been associated with neuroinflammatory processes and is considered a risk factor for the development of neurodegenerative diseases. Volcanic environments are considered a natural source of air pollution. However, the effects of natural source air pollution on the central nervous system (CNS) have not been reported, despite the fact that up to $10 \%$ of the world's population lives near a historically active volcano. In order to assess the response of the CNS to such exposure, our study was conducted in the island of Sao Miguel (Azores, Portugal) in two different areas: Furnas, which is volcanically active one, and compared to Rabo de Peixe, a reference site without manifestations of active volcanism using Mus musculus as a bioindicator species. To evaluate the state of the astroglial population in the dentate gyrus in both samples, the number of astrocytes was determined using immunofluorescence methods (anti-GFAP and anti-GS). In addition, the astrocytic branches in that hippocampal area were examined. Our results showed an increase in GFAP+ astrocytes and a reduction in GS+ astrocytes in Furnas-exposed mice compared to animals from Rabo de Peixe. In addition, astrocytes in the dentate gyrus of chronically exposed animals exhibited longer branches compared to those residing at the reference site. Thus, reactive astrogliosis and astrocyte dysfunction are found in mice living in an active volcanic environment.
\end{abstract}

\section{KEYWORDS}

glial fibrillary acidic protein; astrocytes; Mus musculus; neurotoxicity

\section{Introduction}

There are currently numerous human settlements in the vicinities of volcanoes attributed to some benefits obtained from volcanic activity such as the richness of soil nutrients or tourist attractions. The Ring of Fire in the Pacific Ocean, the island arc systems of Southeast Asia, the Azorean, and the Hawaiian oceanic archipelagos are some examples of these human settlements (Small and Naumann 2001). Various investigators reported that the health of people residing close to an active volcano is threatened by the particular environmental characteristics of volcanism (Amaral and Rodrigues 2011; Durand and Grattan 2001; Hansell, Horwell, and Oppenheimer 2006; Hansell and Oppenheimer 2004; Horwell 2007; Weinstein, Horwell, and Cook 2013). Usually, the communities concern is mainly focused on those threats arising from the volcano explosive activity; however, little is known regarding the disrupting biological effects of toxic gases or particulate matter (PM) released by the volcanic systems, not only during an eruption episode but also through fumarolic fields and soil degasification during the volcano quiescent phases. Due to the growing awareness regarding human health effects from chronic exposure to degassing volcanic activity, some investigators identified hydrothermal regions like the Azores islands (Amaral and Rodrigues 2007; Linhares et al. 2015; Rodrigues, Arruda, and Garcia 2012), Miyakejima Island (Ishigami et al. 2008; Iwasawa et al. 2015), Hawaii (Tam et al. 2016), Iceland (Kristbjornsdottir and Rafnsson 2012) and New Zealand (Bates et al. 2015).

The Azores archipelago (Portugal) is formed by nine volcanic islands, some of which exhibit numerous manifestations of active volcanism. The largest one, São Miguel Island has three major active volcanos: Sete Cidades, Fogo, and Furnas. Furnas volcano activity is characterized by hydrothermal manifestations such as fumarolic fields, thermal and cold carbon dioxide $\left(\mathrm{CO}_{2}\right)$-rich springs and soil degasification. Furnas volcano primary components of total gaseous emissions include vapor $\left(\mathrm{H}_{2} \mathrm{O}\right)$ and $\mathrm{CO}_{2}$ (Amaral and 
Rodrigues 2011), but radon $\left({ }^{222} \mathrm{Rn}\right)$, hydrogen sulfide $\left(\mathrm{H}_{2} \mathrm{~S}\right)$, and other gases are also released into the environment. Carbon dioxide emissions are approximately 1000 tonnes/day (Viveiros et al. 2010). This is an asphyxiant gas also considered as an activator of inflammatory processes (Coakley et al. 2002; Norozian et al. 2011). Several investigators demonstrated that $\mathrm{CO}_{2}$ inhalation leads to a blood-brain barrier (BBB) disruption and therefore, to brain edema (Cameron, Davson, and Segal 1969; Clemedson, Hartelius, and Holmberg 1958; Cutler and Barlow 1966; Huang et al. 2013; Pakulski 1998).

In Furnas village, the indoor ${ }^{222} \mathrm{Rn}$ is usually at a higher concentration than the recommended by the World Health Organization (WHO) (Silva et al. 2015). This radioactive gas is considered as the second leading cause of lung cancer (Tracy et al. 2006). Radon is also known to induce DNA damage (Linhares et al. 2016; Rodrigues, Arruda, and Garcia 2012; Tong et al. 2012) and immune system alterations (Nagarkatti, Nagarkatti, and Brooks 1996), related to the appearance of brain tumors in exposed communities (Bräuner et al. 2013) and neurological disorders (Bølviken et al. 2003; Groves-Kirkby et al. 2006). Finally, $\mathrm{H}_{2} \mathrm{~S}$ is also generally emitted by the volcano and noted to be harmful at low doses initiating cytochrome oxidase inhibition and thus disrupting electron chain transport. Heart and nervous tissue are the most affected due to their high oxygen demand (WHO 2003). In addition to gases, Furnas volcanic environment releases several toxic metals that are bioavailable for animals and humans. Amaral et al. (2007) found that mice residing in Furnas showed a significantly higher load of aluminum (Al), cadmium $(\mathrm{Cd})$, lead $(\mathrm{Pb})$, and zinc $(\mathrm{Zn})$ in lung, liver, or kidney, than animals captured at Rabo the Peixe or in other heavily polluted areas. Amaral et al. (2007) also demonstrated a concomitant increase in apoptosis and metallothioneins production in mice exposed to the active volcanic environment. Further, Ferreira et al. (2015) reported that mice from Furnas possessed higher loads of several metals, including $\mathrm{Cd}, \mathrm{Pb}$, mercury $(\mathrm{Hg})$, nickel $(\mathrm{Ni})$, and chromium $(\mathrm{Cr})$ compared to Rabo de Peixe individuals. With respect to the human population living in Furnas Village settled inside the volcano crater, men displayed higher concentrations of several metals in hair than men from Santa Maria (an island without any volcanic activity), regardless their age (Amaral et al. 2008).
Apart from other metals, gaseous elemental mercury $\left(\mathrm{Hg}^{0}\right)$ is also released by volcanic activity into the atmosphere (Gustin, Lindberg, and Weisberg 2008; Selin 2009). Bagnato et al. (2018) estimated the amount $\left(9,6 \times 10^{-5} \mathrm{t} \mathrm{d}^{-1}\right)$ of gaseous $\left(\mathrm{Hg}^{0}\right)$ released by the Furnas volcano in a small study area of $0.04 \mathrm{~km}^{2}$. Recently, Navarro-Sempere et al. (2020) found appreciable amounts of $\mathrm{Hg}$ deposits in blood vessels, white matter, and some cells of the hippocampus in wild mice that resided within the caldera of the Furnas volcano, warning for the possibility of being a causative factor of neurodegenerative diseases (Farina et al. 2013; TiffanyCastiglioni and Qian 2001)

The association between air pollution and neurodegenerative diseases has only recently been established (Jayaraj et al. 2017) and the effects of volcanogenic air pollution have thus far not been examined. Considering that the dimension of volcanic emissions of certain gases is comparable to anthropogenic ones (Hansell and Oppenheimer 2004) and more than 44 million of individuals residing within $10 \mathrm{~km}$ of an active volcano (Holmberg and Small 2015), it is important to determine the influence of volcanogenic pollutants on the central nervous system (CNS).

Air pollution affects the brain through different paths including molecular, cellular, and inflammatory (Genc et al. 2012). The toxic gases and other air contaminants induce the production of proinflammatory cytokines that reach the CNS through the brain-blood barrier (BBB) or directly through the olfactory epithelium. These neuroinflammatory processes trigger a response in the brain glial cells, which constitute the immune system in the CNS. Astrocytes, the most abundant glial cell type of the CNS, are responsible for (1) maintaining brain homeostasis, (2) providing metabolites to neurons, (3) synapses monitoring, (4) regulating the extracellular balance of ions and neurotransmitters, and (5) taking part in BBB maintenance and permeability (Sofroniew 2009). Astrocytes are immunocompetent cells and therefore, respond to CNS injuries by activating and producing cytokines or initiating the immune adaptive responses (Cordiglieri and Farina 2010; Farina, Aloisi, and Meinl 2007). Certain cytokines, such as tumor necrosis factor alpha (TNF $\alpha$ ), ciliary neurotrophic factor (CNTF), or interleukin 6 (IL-6) induce astrocytic activation. This activation is not a single none-or-all 
response, but a multifaceted process involving modifications in gene expression and cell morphology. Astrocytic activation is controlled in a time- and context-dependent way, which indicates that this process might play a beneficial role but might also lead to harmful effects.

The activation and proliferation of this glial population was noted in several neurodegenerative diseases: Alzheimer's (AD), amyotrophic lateral sclerosis (ALS), multiple sclerosis, and Parkinson's disease (PD) (Abdelhak et al. 2018; Eddleston and Mucke 1993; Maragakis and Rothstein 2006; Niranjan 2014; Sofroniew and Vinters 2010). Therefore, astrocytes proliferation and its presence in the reactive form suggest that neuroinflammatory processes may be taking place since astrocytes are considered active players in neuroinflammation (Colombo and Farina 2016).

Two important astrocytes hallmarks are the presence of glutamine synthetase (GS) and glial fibrillary acidic protein (GFAP). One of the fundamental roles of astrocytes is to protect neurons from excitotoxicity, collecting excess ammonia and glutamate from the extracellular space through the GS pathway. Thus, alterations in this enzyme expression suggest changes in astrocytic function that might affect neuronal activity (Son et al. 2019; Suárez, Bodega, and Fernández 2002). In contrast, GFAP is a protein marker of the astrocytes intermediate filaments and overexpression arises in response to CNS insults (Abdelhak et al. 2018; Colombo and Farina 2016; Lana et al. 2017; Niranjan 2014; Sofroniew 2009; Steward, Kelley, and Torre 1993), including those derived from air pollution as was demonstrated by Calderón-Garcidueñas et al. (2008).

Sofroniew and Vinters (2010) recognized the presence of reactive astrocytes in the hippocampus during inflammation. The dentate gyrus (DG), a region of hippocampal formation with a regular organization of its principal cell layers, is used as a model system for many facets of modern neurobiology (Amaral and Lavenex 2007) and further, it is the first region where all sensory modalities come together and play a critical role in learning and memory. This area seems markedly affected by volcanogenic pollutants since Navarro-Sempere et al. (2020) reported the existence of intracellular deposits of mercury in DG cells. Considering the characteristics of active volcanic environments, we hypothesize that chronic exposure to hydrothermal hazardous emissions could be a risk factor for brain neuroinflammatory processes and neurodegenerative diseases, associated with astrocyte proliferation and dysfunction. For that purpose, we have studied the hippocampal dentate gyrus of wild mice (used as surrogate species), since it is a vulnerable structure to neuroinflammatory processes and neurodegenerative diseases (Hedden and Gabrieli 2004; Small et al. 2002), such as Alzheimer's disease (Li et al. 2008; Rodríguez et al. 2008) or Parkinson's disease (Marxreiter, Regensburger, and Winkler 2013).

\section{Material and methods}

\section{Animals}

Mus musculus was the species selected to perform this study because these animals are found in both active and inactive volcanic environments and shares the habitat with humans. Several investigators demonstrated that field-captured specimen studies are the best option to evaluate the influence of environmental exposure to pollutants, as there are discrepancies with lab research due to the animal diets, behavior, or contaminants mix (Forsyth 2001; Tersago et al. 2004).

\section{Specimen collection and study sites}

Mice were captured on the São Miguel Island, the largest of the archipelago of the Azores (Portugal), formed by three major active central volcanoes (Sete Cidades, Fogo, and Furnas) (Figure 1a,b). Two groups of Mus musculus were caught alive in two different locations (Figure 1b): Furnas village (exposed group) and Rabo de Peixe village (control group).

Furnas village has a population of about 1500 inhabitants and is located inside the Furnas volcano crater. Volcanic activity in Furnas village is currently marked by several hydrothermal manifestations including soil diffuse degassing, thermal and cold carbon dioxide $\left(\mathrm{CO}_{2}\right)$-rich springs and fumarolic fields (Viveiros et al. 2010).In this village, approximately $58 \%$ of the buildings are located above anomalous soil $\mathrm{CO}_{2}$ diffuse degassing of volcanic-hydrothermal origin (Viveiros et al. 2010; 2012). Fumarole gaseous emissions are predominantly comprised of water (steam), and $\mathrm{CO}_{2}, \mathrm{H}_{2} \mathrm{~S}, \mathrm{H}_{2}, \mathrm{~N}_{2}, \mathrm{O}_{2}, \mathrm{CH}_{4}$, and Ar are present in lower concentrations (Ferreira et al. 2005); soil gas 


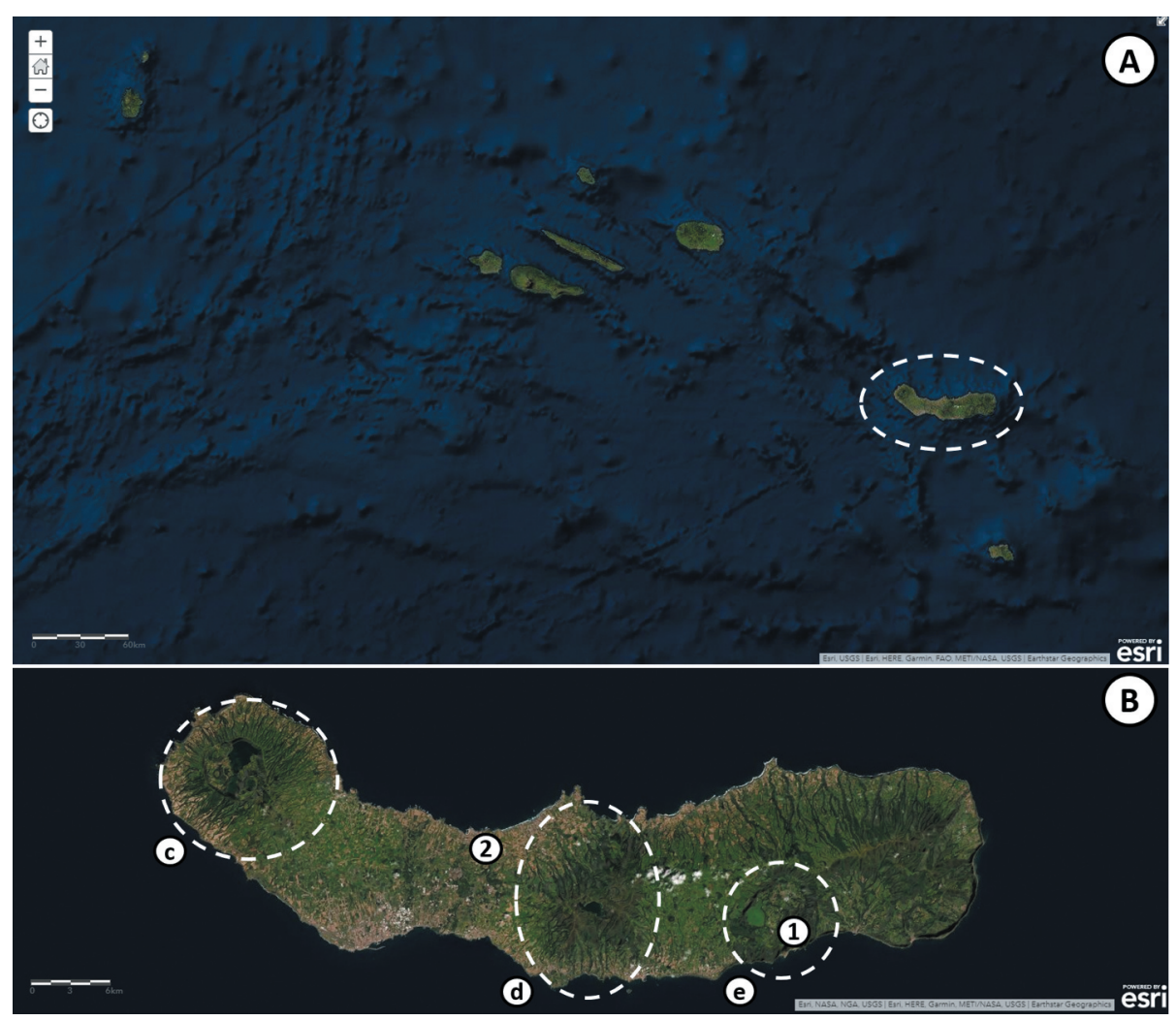

Figure 1. Map of the Azores Archipelago. (a) Morphotectonic features of the Azorean archipelago. White dashed circle indicates the S. Miguel Island; (b) Map of S. Miguel Island and study areas. 1 - Furnas, 2 - Rabo de Peixe; white dashed circles represent the main volcanic complexes of: c - Sete Cidades, d- Fogo, e - Furnas. Basemap aerial view backgrounds by ESRI ArcGIS online. "World Imagery" [basemap]. "World Imagery Map". Last updated 11/06/2020. https://www.arcgis.com/home/item.html?id=10df2279f9684e4a9f6a7f08 febac2a9. Attribution information to both ESRI and other data providers illustrated in the Figure.

emissions are essentially $\mathrm{CO}_{2}$ and ${ }^{222} \mathrm{Rn}$ (Silva et al. 2015; Viveiros et al. 2010). In addition, the active degassing areas contribute to the continuous input of volatile metals into the atmosphere (Bagnato et al. 2014; 2018; Durand et al. 2004).

Rabo de Peixe is a rural village with 5000 inhabitants located $24 \mathrm{~km}$ away from Furnas and has no active manifestations of volcanism since the seventieth century (Carvalho 1999) or significant anthropogenic pollution sources.

Ten mice (Furnas, $\mathrm{N}=5$; Rabo de Peixe, $\mathrm{N}=5$ ) were caught using mouse traps at both locations. The individuals were kept alive for the shortest possible time (up to $24 \mathrm{hr}$ ) before euthanasia with isofluorane. Upon reaching an optimal anesthesia level, mice were transcardiacally perfused with phosphate saline buffer followed by $4 \%$ paraformaldehyde (PFA). Subsequently, mouse brains were extracted and fixed in 4\% PFA overnight. For each mouse, the following data were collected: body weight, gender, and age. The age of each mouse was determined based upon dry crystalline lens mass as described by Quere and Vincent (1989).

Experimental procedures were approved by the University of the Azores. All procedures were carried out in strict accordance with the recommendations of the European Convention for the Protection of Vertebrate Animals used for Experimental and Other Scientific Purposes (ETS 123), directive 2010/ 63/EU and Portuguese law (DL 113/2013).

\section{Histological processing and immunofluorescence}

The brains were paraffin embedded and $4 \mu \mathrm{m}$ sagittal sections were cut using a microtome (Microm HM 340E). Immunofluorescence assay was carried out in selected sections containing the hippocampus. Samples were incubated with primary antibodies, anti-GFAP (HPA056030, Sigma Aldrich Co.), and anti-glutamine synthetase (G2781, Sigma Aldrich Co.) at 1:200 overnight at $4^{\circ} \mathrm{C}$. The next day, sections were washed and incubated with the secondary 
antibody (SAB4600310, Sigma Aldrich Co, 1:500), for $2 \mathrm{hr}$ at room temperature with agitation. Subsequently, sections were washed several times, dried, and covered in the dark with Vectashield medium (Vector Laboratories, Burlingame CA, USA) containing DAPI to counterstain nuclei.

\section{Quantitative analysis}

Zeiss confocal laser scanning microscope was employed to take confocal hippocampal scans at $20 \mathrm{x}$ magnification, every $0.5 \mu \mathrm{m}$ z-step and mounted in an orthogonal projection using Zen Blue software. Three coronal sections spaced by $150 \mu \mathrm{m}$ were analyzed keeping constant pinhole, contrast, and brightness. The region of interest (ROI) for the tests was hippocampal dentate gyrus (DG) where two separate subareas were examined: polymorphic layer (PL) and granular layer (GL) (Figure 2). Areas of GL and PL were measured in $\mu \mathrm{m}^{2}$ and later expressed in $\mathrm{mm}^{2}$ to calculate the number of immunopositive cells per $\mathrm{mm}^{2}$. All quantifications and counts were conducted blindly and independently by three different researchers using the ImageJ software and the results were averaged. Three GFAP+ astrocytes were randomly selected in each subarea (PL and GL) to measure the length of the four astrocyte principal branches in all animals from both study areas. This analysis was carried out blindly using ImageJ software and results averaged.

\section{Statistical analysis}

The concentration of GFAP+ and GS+ astrocytes and length of astrocyte branches in each subarea were compared between both mice populations, using Student's t-test and the level of significance was set at $p<.05$. Graph Pad Prism was used to perform all statistical analysis (Graph Pad Software Inc., La Jolla, CA, USA).

\section{Results}

The average age (in days) of mice was similar between studied groups (112 \pm 8 , Furnas village; $133 \pm 9$; Rabo de Peixe). No statistical difference in weight was found

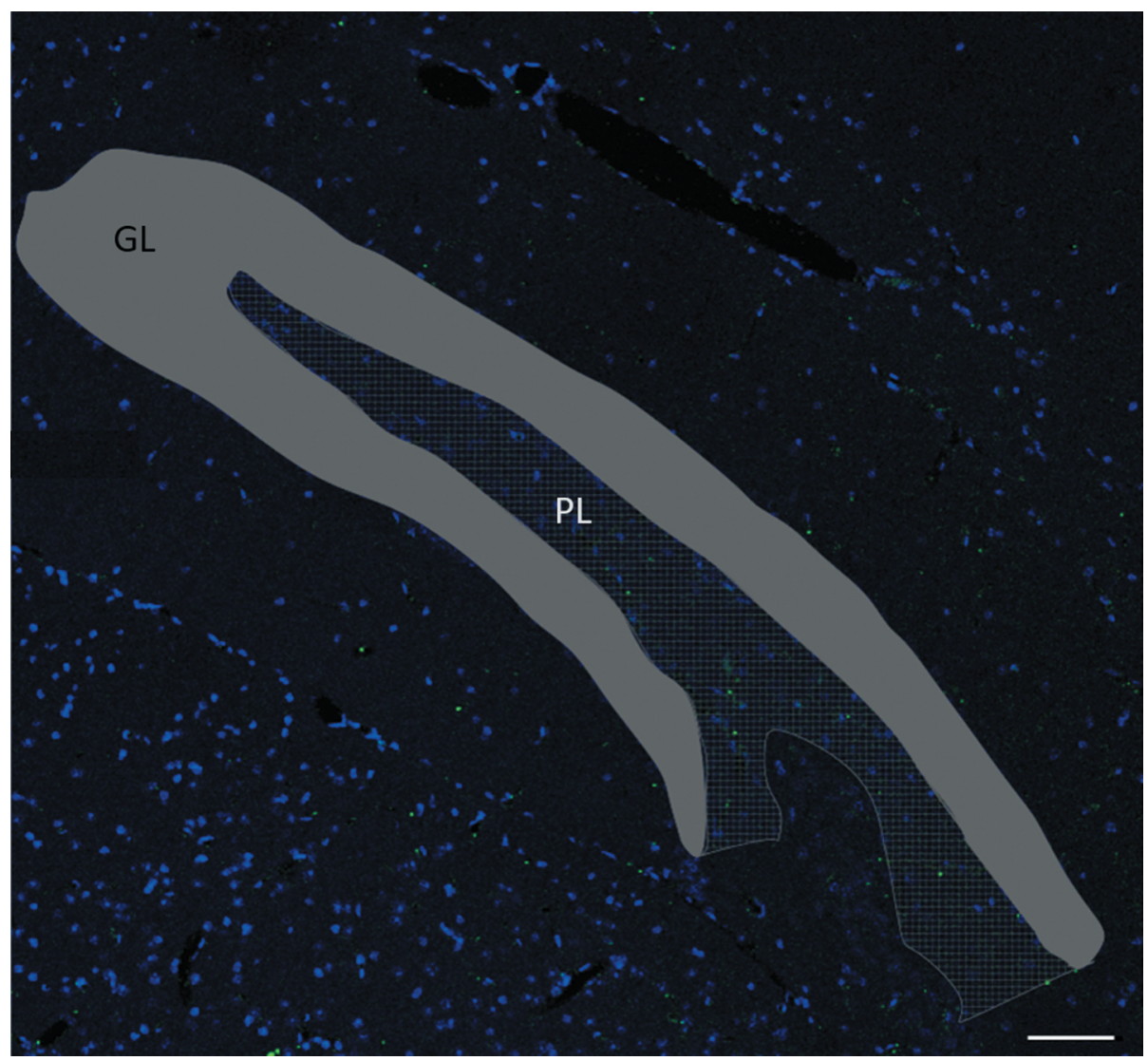

Figure 2. Representative image of the region of interest (ROI). Dentate gyrus was divided in two parts: granular layer (GL, gray area) and polymorphic layer (PL, gridded area). Scale Bar: $50 \mu \mathrm{m}$. 
between studied groups $(13,25 \pm 0.79 \mathrm{~g}$, Furnas village; $14.52 \pm 0.41$ g; Rabo de Peixe).

Astrocytes were identified using fluorescent immunostaining for GFAP and GS aiming to determine the presence of neuroinflammation processes in those mice chronically exposed to the active volcanic environment. As illustrated in the representative images of Figures 3-6, astrocytes were immunolabeled with anti-GFAP antibody (Figure 3) and anti-GS antibody (Figure 5) and counted separately in GL and PL in Furnas and Rabo de Peixe mice.

\section{GFAP quantification in dentate gyrus}

A qualitative increase of GFAP fluorescence intensity was noted in the DG from Furnas compared to Rabo de Peixe mice (Figure 3). Regarding the quantification, the number of GFAP positive cells was higher in individuals from Furnas than those from Rabo de
Peixe in both PL $\left(1405,60 \pm 64,33\right.$ cells $/ \mathrm{mm}^{2}$ vs. $992,66 \pm 56,88$ cells $\left./ \mathrm{mm}^{2}\right)$ and GL $(1678,30 \pm 91,12$ cells $/ \mathrm{mm}^{2}$ vs. $1148,39 \pm 37,79$ cells $/ \mathrm{mm}^{2}$ ) (Figure 4 ). A significant elevation was found in the number of astrocytes in both PL (+41.6\%) and GL (+46.14\%) (Figure 4).

\section{Glutamine synthetase in dentate gyrus}

A diminished GS fluorescent intensity in Furnas samples was observed when compared to Rabo de Peixe (Figure 5). Quantitative analysis showed that the number of GS+ astrocytes was less in DG from Furnas than Rabo de Peixe animals, both in PL $\left(955,39 \pm 31,39\right.$ cells $/ \mathrm{mm}^{2}$ vs. $1201,55 \pm 66,47$ cells $\left./ \mathrm{mm}^{2}\right)$ and GL $\left(1321,92 \pm 62,37\right.$ cells $/ \mathrm{mm}^{2} v s$. $1546,17 \pm 50,34$ cells $/ \mathrm{mm}^{2}$ ). This reduction in the number of GS+ astrocytes was significant in $\mathrm{PL}$ $(-20.49 \%)$ and GL $(-14.5 \%)$ (Figure 6).
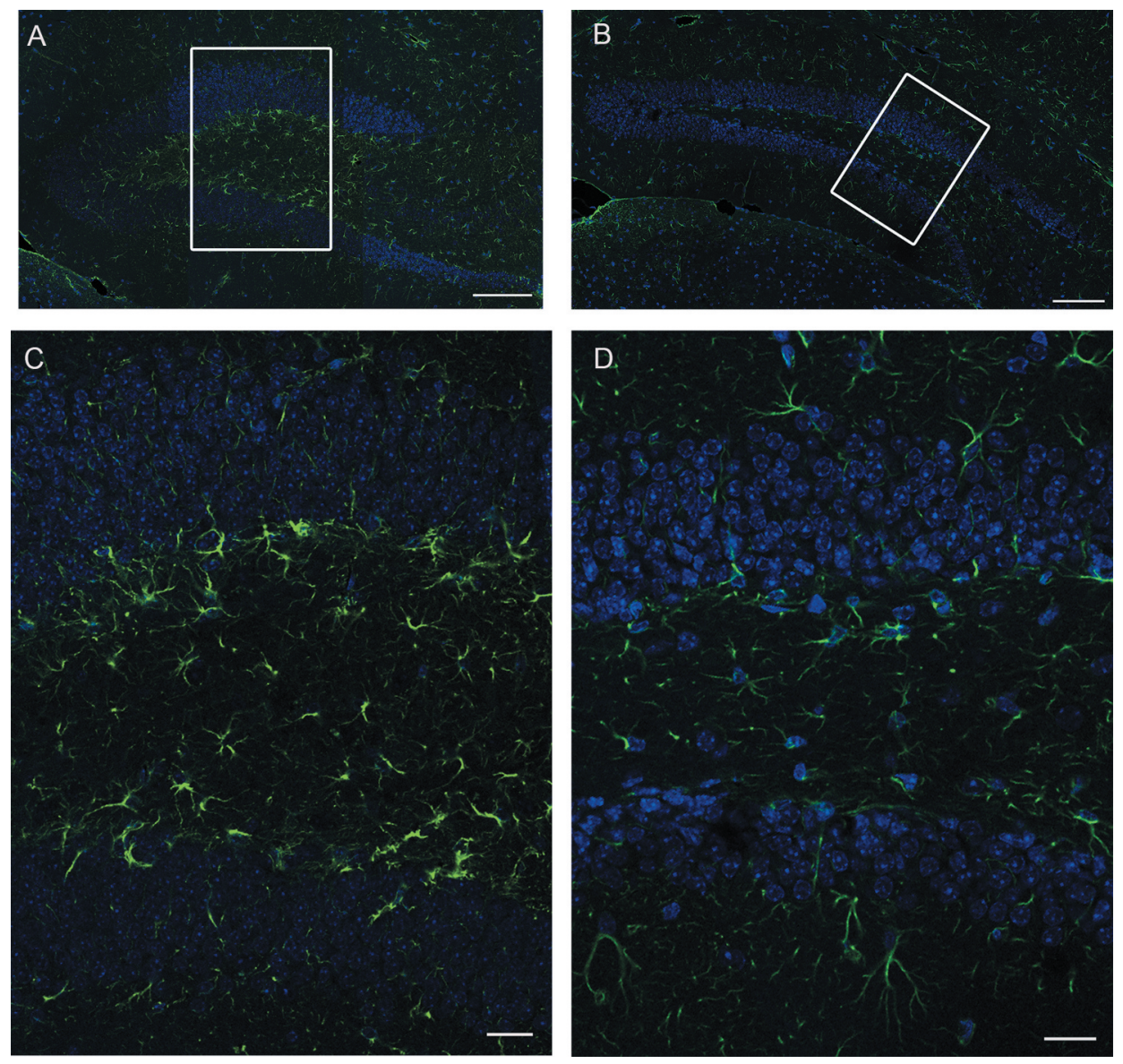

Figure 3. GFAP immunofluorescence in mice dentate gyrus from Furnas (a) and Rabo de Peixe (b). Scale bar: $100 \mu \mathrm{m}$. (c) Amplified inset image from (a). Scale bar: $20 \mu \mathrm{m}$. (d) Amplified inset image from B. Scale bar: $20 \mu \mathrm{m}$. Note a qualitative difference in GFAP expression between Furnas $(a, c)$ and Rabo de Peixe $(b, d)$ samples. GL, granular layer; PL, polymorphic layer. 


\section{GFAP+}

\section{(A) Polymorphic layer}

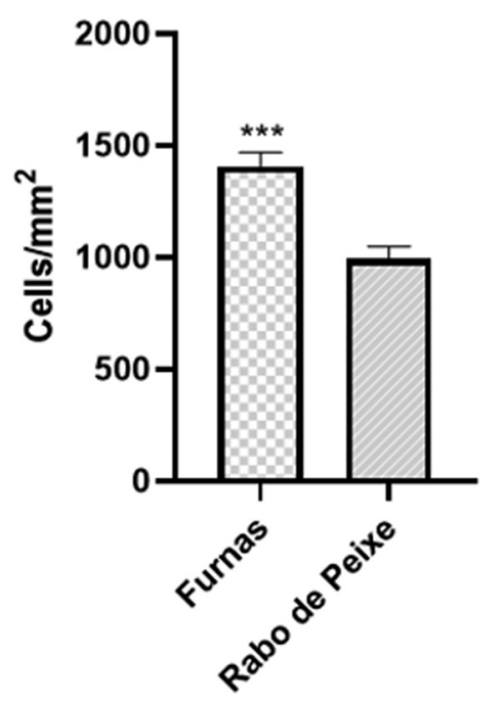

(B) Granular layer

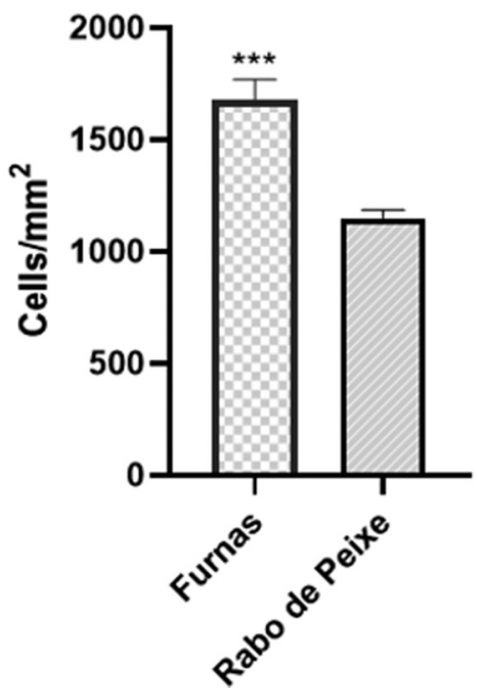

Figure 4. Quantitative analysis of GFAP+ astrocytes in polymorphic layer (a) and granular layer (b). In both dentate gyrus areas, number of GFAP+ astrocytes were significantly more numerous in Furnas mice than Rabo de Peixe animals (Student's t-test, $\left.{ }^{*} p<.05\right)$. Data represented in the graph bars are expressed as mean $\pm \mathrm{SE}$.
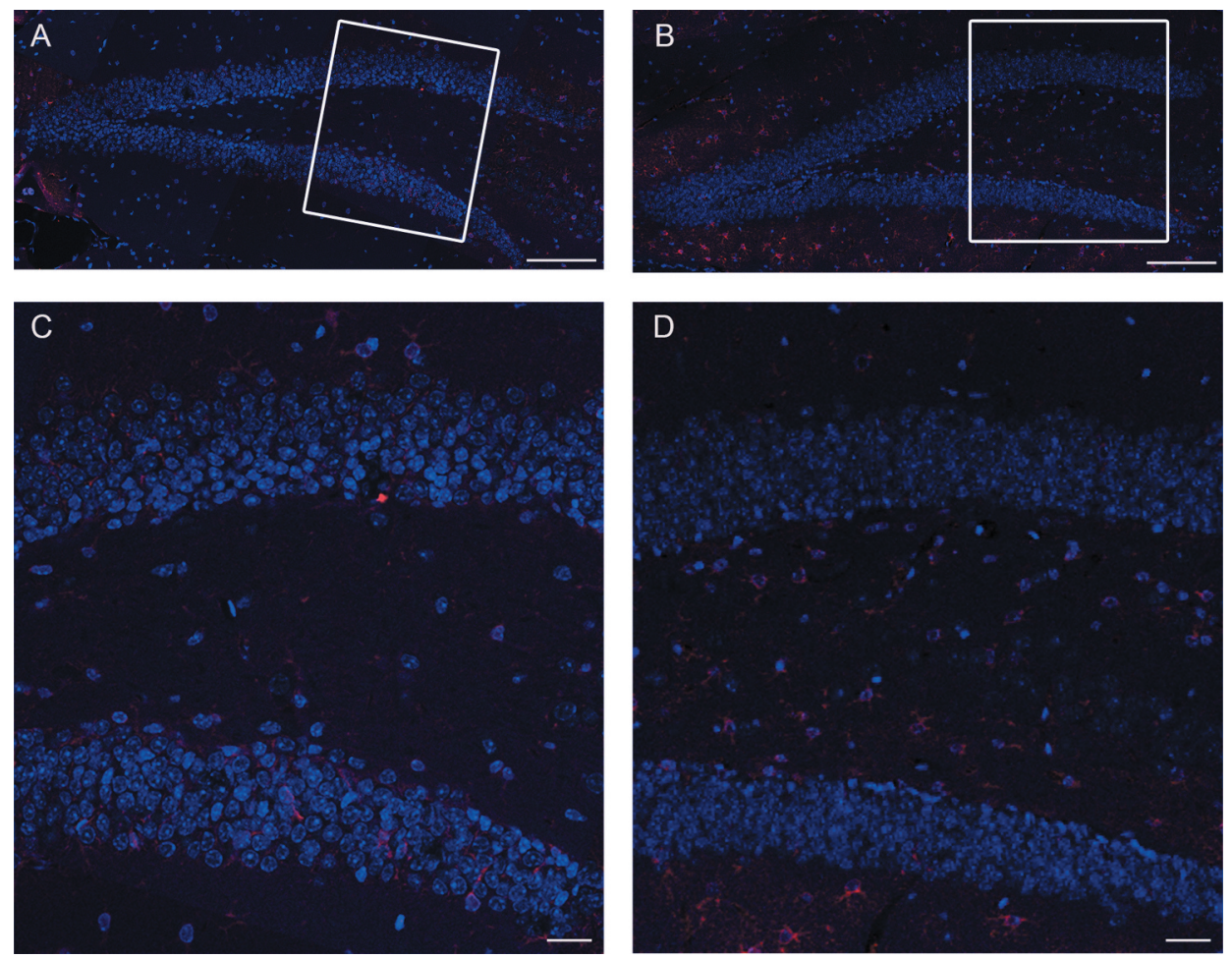

Figure 5. Photomicrographs of GS immunofluorescence in the dentate gyrus of the individuals caught in Furnas (a) and those living in Rabo de Peixe (b). Scale bar: $100 \mu \mathrm{m}$. (c) Magnification of the framed area in A. Scale bar: $20 \mu \mathrm{m}$ (d) Magnification of the framed area in B. Scale bar: $20 \mu \mathrm{m}$. There is a marked qualitative difference in the number of GS+ astrocytes between Furnas $(\mathrm{a}, \mathrm{c})$ and Rabo de Peixe $(\mathrm{b}, \mathrm{d})$ mice. GL, granular layer; PL, polymorphic layer. 


\section{GS+}
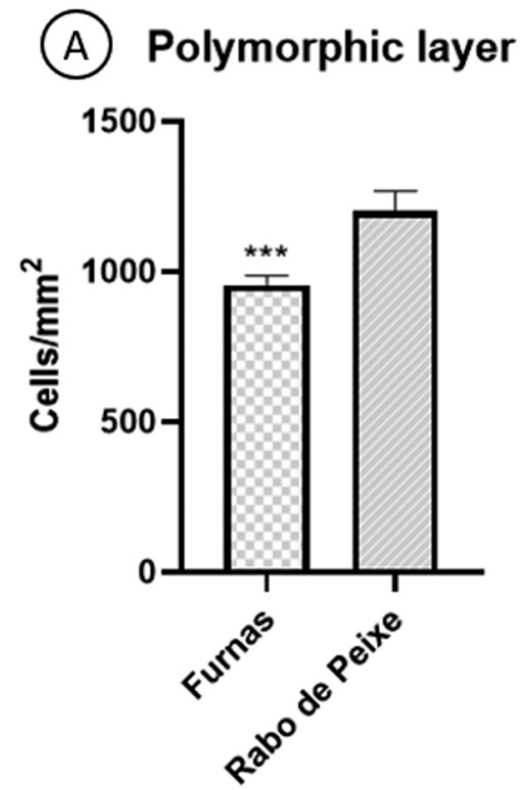

(B) Granular layer

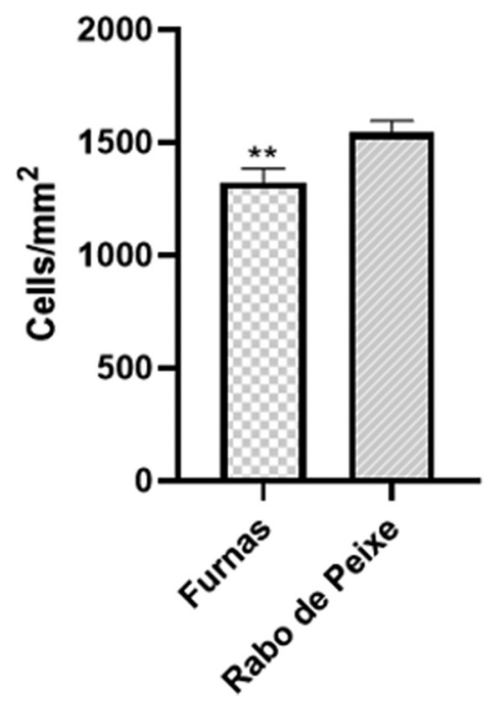

Figure 6. Quantitative analysis of GS+ astrocytes in polymorphic layer (a) and granular layer (b) of the dentate gyrus in study animals. The number of astrocytes GS+ was significantly less numerous in Furnas mice than in those from Rabo de Peixe (Student's t-test; $\left.{ }^{*} p<.05\right)$. Data represented in the graph bars were expressed as mean $\pm \mathrm{SE}$.

\section{Astrocytes branches morphological analysis}

The length of four main branches of randomly GFAP + selected astrocytes was determined utilizing a magnified image (Figure 7), both in PL and in GL and compared. The astrocytes from mice caught in Furnas exhibited longer branches than those from Rabo de Peixe in both ROI subareas: the PL $(13,29 \mu \mathrm{m} \pm$ $1,37 \mu \mathrm{m} v s .9 .04 \mu \mathrm{m} \pm 0.49 \mu \mathrm{m})$ and GL $(12,76 \mu \mathrm{m} \pm$

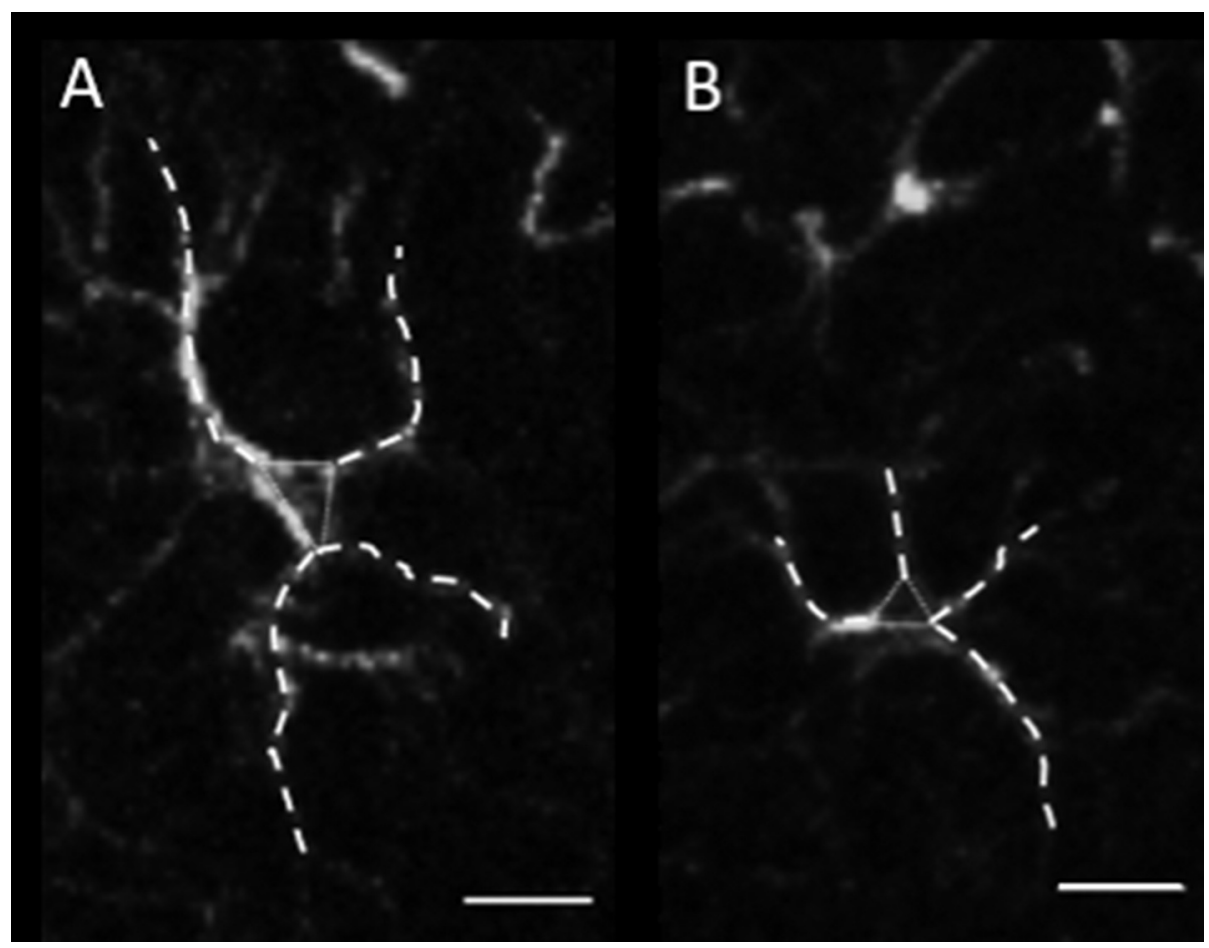

Figure 7. Magnification of two GFAP+ astrocytes found in the dentate gyrus of mouse from Furnas (a) and one from Rabo de Peixe (b). This image is a schematic representation of the method used to measure 4 principal branches of the GFAP+ astrocytes. Scale bar: $5 \mu$ m. 
$1,32 \mu \mathrm{m} v s .8,82 \mu \mathrm{m} \pm 0.48 \mu \mathrm{m})$. This difference in principal branches length was significant in PL $(+47 \%)$ and GL (+45\%) (Figure 8).

\section{Discussion}

Data demonstrated the presence of reactive astrogliosis in the DG of the hippocampus attributed to living in an active volcanic environment. The hippocampus has been considered a target structure for neurotoxic agents as abuse of drugs, neuroactive virus, or environmental pollutants (Harry and D'Hellencourt 2003; Walsh and Emerich 1988). It is of interest that the DG seems to be affected by a chronic exposure to volcanogenic air pollution (Navarro-Sempere et al. 2020). Consequently, it is an ideal structure to examine different astroglial dysfunction processes. Further, it is well established that astrocytes are highly differentiated cells that contribute to the proper functioning of a healthy CNS, in addition to responding to damage and disease through a process termed reactive astrogliosis (Sofroniew 2009). Pekny, Wilhelmsson, and Pekna (2014) identified two prominent hallmarks that are produced in reactive astrogliosis: (1) hypertrophy of the astrocytic branches and (2) upregulation of the intermediate filament proteins, especially
GFAP. The animals captured in Furnas village displayed a significant rise in the number of GFAP+ astrocytes and branches morphological changes compared to mice caught in the control area, Rabo de Peixe, in which astrocytes exhibited normal morphology.

Sofroniew and Vinters (2010) suggested several molecules that activate the process of reactive astrogliosis including the tumor necrosis factor alpha (TNF a), which plays an important role in the activation of inflammation (Zhang et al. 2010). Recently Camarinho et al. (2019) demonstrated that this pro-inflammatory cytokine is overproduced in the exposed mice in this same volcanic area; consequently, TNFa might reach the brain by crossing the $\mathrm{BBB}$ and activating astrocytes.

Living in volcanic areas with hydrothermal activity, where concentrations of $\mathrm{CO}_{2}$ are elevated, might result in an increase of this gas in the blood, a phenomenon known as hypercapnia. Furnas village is an example of a volcanic area where environmental $\mathrm{CO}_{2}$ concentrations exceed the limits established by the Occupational Safety and Health Administration (OSHA) of the USA (Amaral and Rodrigues 2011). Hypercapnia produces an elevation of nitric oxide synthase (NOS) in brain isoforms and, consequently,

\section{Astrocyte branches}

(A)

\section{Polymorphic layer}

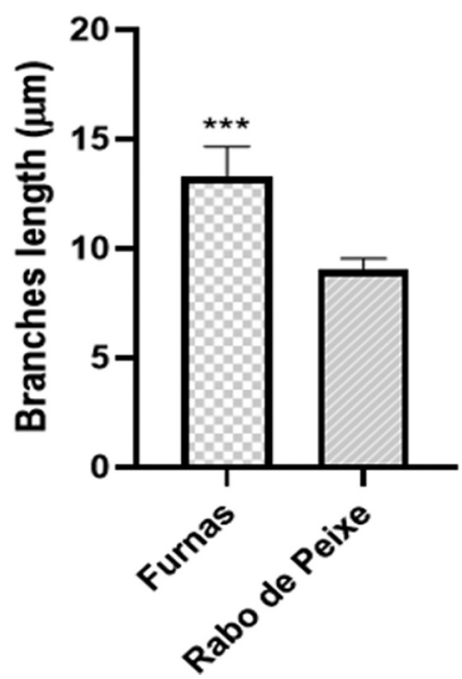

(B)

Granular layer

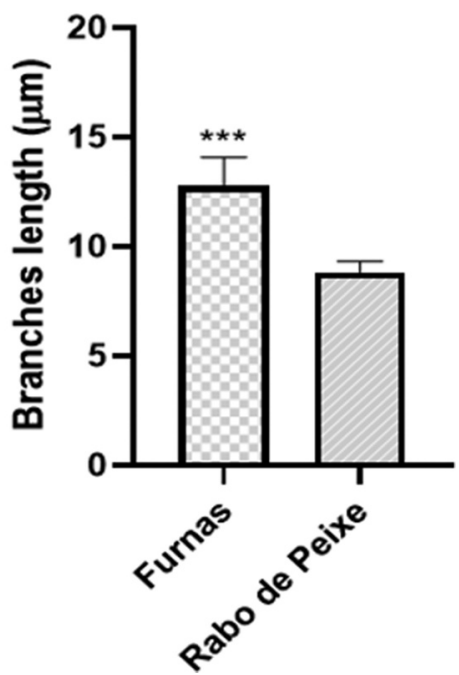

Figure 8. Analysis of the principal branches of GFAP+ astrocytes. Mice from Furnas showed significantly longer branches than individuals from Rabo de Peixe in polymorphic layer (a) and granular layer (b) (Student's t-test; ${ }^{*} p<0,05$ ). Data represented in the graph bars were expressed as mean $\pm \mathrm{SE}$. 
the amount of the nitric oxide (NO) in the brain increases (Peebles et al. 2008). In addition, NO, which is a powerful vasodilator, enhances cerebrovascular flow adversely affecting the BBB and thus blood vessels dilate giving rise to the disunity of $\mathrm{BBB}$ tight junctions (Thiel and Audus 2001). These processes yield an elevation in barrier permeability whereby multiple molecules and toxins might reach the brain parenchyma while do not occur in normal conditions.

It is well known the CNS is highly susceptible to the harmful effects of reactive oxygen species (ROS) (Pałasz et al. 2019), another group of molecules described by Sofroniew and Vinters (2010) as capable of triggering astrogliosis. Several investigators suggested that NO synthesized by the neural NOS (nNOS) deactivate the GS enzyme (Görg et al. 2005; McBean et al. 1995; Miñana et al. 1997) and attenuate glutamate uptake by astrocytes (Suárez, Bodega, and Fernández 2002), leading to reactive astrogliosis. It is known that astrocytes are responsible for $80-90 \%$ of glutamate uptake (Rose et al. 2018; Rose, Verkhratsky, and Parpura 2013) to protect neurons from excitotoxic damage by rapidly converting glutamate to glutamine, using GS enzyme (Muse et al. 2001). The activity and expression of this enzyme might be diminished in the presence of TNFa (Kazazoglou et al. 1996; Zou et al. 2010). Data demonstrated that TNFa affects glutamate uptake by astrocytes through the negative regulation of glutamate transporters (Sitcheran et al. 2005; Wang et al. 2003). If glutamate uptake is adversely affected, apart from the toxicity derived from reaching a high level of extracellular glutamate, many metabolic pathways might be impaired and thus, uptake is a critical step for a wellfunctioning brain.

Our results demonstrated that mice chronically exposed to an active volcanic environment exhibited a significant reduction in the number of astrocytes GS $+/ \mathrm{mm}^{2}$ compared to those from the control area which may reflect astrocyte dysfunction. Therefore, the amount of GS enzyme in the DG from mice residing in Furnas village is less, a fact that may be due to an increase in production of $\mathrm{NO}$ and $\mathrm{TNF} \alpha$ derived from the exposure to a high $\mathrm{CO}_{2}$ environment and other volcanogenic pollutants, such as $\mathrm{Rn}^{222}, \mathrm{H}_{2}$ $\mathrm{S}$ or $\mathrm{Hg}^{0}$. As indicated previously, the GS enzyme exerts a neuroprotective role against glutamate and ammonia excess, preventing its accumulation in the synaptic cleft. Our findings showed that animals chronically exposed to volcanogenic contaminants exhibit a decrease in GS enzyme and, consequently, it is conceivable that these animals accumulate extracellular ammonia since it is not metabolized by GS. Further, ammonia is known to be as an agent capable of activating astrocytes (Sofroniew and Vinters 2010).

Data demonstrated that chronic exposure to active volcanic environments triggers an astrogliosis reactive response and astrocyte dysfunction in the DG. Previously investigators reported that astrocyte reactivity plays an adaptive role, enabling restoration of system homeostasis, limiting tissue damage, and coping with acute stress. In such cases, an increase in neuronal death was observed and tissue degeneration was exacerbated (Faulkner et al. 2004; Myer et al. 2006) or repair of the BBB is impaired (Bush et al. 1999). Nevertheless, if this response persists over time as it might be possible in individuals from Furnas village, a situation of continuous stress and chronic neuroinflammation might appear and then, play an important role in the pathogenesis of neurodegenerative diseases (Kempuraj et al. 2016). Acute neuroinflammation is critical in eliminating toxins, infective agents, and dead cells to protect the CNS from damage or repair (Russo and McGavern 2015; 2016). In contrast, long-term inflammatory reactions, with a high level of proinflammatory mediators and active glial cells, perform opposite functions, leading to emergence or progression of neurodegenerative pathologies (Zheng, Zhou, and Wang 2016). In fact, several studies showed the role of the reactive astrogliosis in the pathogenesis of neurodegenerative diseases, including Alzheimer (Nagele et al. 2004; Tarkowski et al. 2003), Parkinson's (Liu, Gao, and Hong 2003; Song et al. 2009) or multiple sclerosis (Hostenbach et al. 2014; Kempuraj et al. 2016).

\section{Conclusions}

Our data demonstrated that chronic exposure to volcanogenic pollutants is associated with reactive astrogliosis and astrocyte dysfunction. The appearance of reactive astrogliosis in hippocampal DG was accompanied by a significant decrease in GS, a key enzyme for neural protection against excitotoxic damage in exposed mice. Consequently, a neuroinflammatory response may occur and sustained over time, and 
subsequently trigger the appearance of different neurodegenerative pathologies. Our findings highlight the importance of monitoring the neurological health of those inhabitants chronically exposed to volcanogenic contaminants since such exposure is associated with health hazards in the brain.

\section{Acknowledgments}

This research was supported by the University of Alicante VIGROB-186. The authors would like to thank Paulo Melo for the field assistance in the capture of Mus musculus.

\section{Disclosure statement}

The authors declare that there are no conflicts of interest.

\section{References}

Abdelhak, A., A. Huss, J. Kassubek, H. Tumani, and M. Otto. 2018. Serum GFAP as a biomarker for disease severity in multiple sclerosis. Sci. Rep. 8 (1):1-7. doi:10.1038/s41598-01833158-8.

Amaral, A., C. Cabral, C. Guedes, and A. Rodrigues. 2007. Apoptosis, metallothionein, and bioavailable metals in domestic mice (Mus musculus L.) from a human-inhabited volcanic area. Ecotoxicology 16 (6):475-82. http://link.springer.com/10. 1007/s10646-007-0156-y.

Amaral, A. F. S., and A. S. Rodrigues. 2007. Chronic exposure to volcanic environments and chronic bronchitis incidence in the Azores, Portugal. Environ. Res. 103:419-23. doi:10.1016/j. envres.2006.06.016.

Amaral, A. F. S., and A. S. Rodrigues. 2011. Volcanogenic contaminants: Chronic exposure. In Encyclopedia of environmental health, edited by J.Nriagu, 681-689. BV, New York: Elsevier.

Amaral, A. F. S., M. Arruda, S. Cabral, and A. S. Rodrigues. 2008. Essential and non-essential trace metals in scalp hair of men chronically exposed to volcanogenic metals in the Azores, Portugal. Environ. Int. 34 (8):1104-08. doi:10.1016/ j.envint.2008.03.013.

Amaral, D., and P. Lavenex. 2007. Hippocampal neuroanatomy. In The hippocampus book, ed. P. Andersen, R. Morris, and D. Amaral, 37-114. New York: Oxford University Press.

Bagnato, E., F. Viveiros, J. E. Pacheco, F. D’Agostino, C. Silva, and V. Zanon. 2018. $\mathrm{Hg}$ and $\mathrm{CO}_{2}$ emissions from soil diffuse degassing and fumaroles at Furnas volcano (São Miguel island, Azores): gas flux and thermal energy output. J. Geochem. Explor. 190:39-57. doi:10.1016/j.gexplo.2018.02.017.

Bagnato, E., M. Barra, C. Cardellini, G. Chiodini, F. Parello, and M. Sprovieri. 2014. First combined flux chamber survey of mercury and $\mathrm{CO}_{2}$ emissions from soil diffuse degassing at Solfatara of Pozzuoli Crater, Campi Flegrei (Italy): mapping and quantification of gas release. J. Volcanol. Geothermal Res. 289:26-40. doi:10.1016/j.jvolgeores.2014.10.017.

Bates, M. N., J. Crane, J. R. Balmes, N. Garrett, and D. O. Carpenter. 2015. Investigation of hydrogen sulfide exposure and lung function, asthma and chronic obstructive pulmonary disease in a geothermal area of New Zealand. PLoS ONE 10 (3):1-16. doi:10.1371/journal.pone.0122062.

Bølviken, B., E. G. Celius, R. Nilsen, and T. Strand. 2003. Radon: a possible risk factor in multiple sclerosis. Neuroepidemiology 22 (1):87-94. doi:10.1159/000067102.

Bräuner, E. V., Z. J. Andersen, C. E. Andersen, C. Pedersen, P. Gravesen, K. Ulbak, O. Hertel, S. Loft, and O. RaaschouNielsen. 2013. Residential radon and brain tumour incidence in a danish cohort. In PLoS ONE, 8 (9):e74435.

Bush, T. G., N. Puvanachandra, C. H. Horner, A. Polito, T. Ostenfeld, C. N. Svendsen, L. Mucke, M. H. Johnson, and M. V. Sofroniew. 1999. Leukocyte infiltration, neuronal degeneration, and neurite outgrowth after ablation of scar-forming, reactive astrocytes in adult transgenic mice. Neuron 23 (2):297-308. doi:10.1016/S0896-6273(00)80781-3.

Calderón-Garcidueñas, L., A. C. Solt, C. Henríquez-Roldán, R. Torres-Jardón, B. Nuse, L. Herritt, R. Villarreal-Calderón, N. Osnaya, I. Stone, R. García, et al. 2008. Long-term air pollution exposure is associated with neuroinflammation, an altered innate immune response, disruption of the blood-brain barrier, ultrafine particulate deposition, and accumulation of amyloid $\beta-42$ and $\alpha$-synuclein in children and young adults. Toxicologic Pathology 36 (2):289-310. http://journals.sagepub. com/doi/10.1177/0192623307313011

Camarinho, R., P. V. Garcia, H. Choi, and A. S. Rodrigues. 2019. Overproduction of TNF- $\alpha$ and lung structural remodelling due to chronic exposure to volcanogenic air pollution. Chemosphere 222:227-34. doi:10.1016/j.chemosphere.2019. 01.138 .

Cameron, I. R., H. Davson, and M. B. Segal. 1969. The effect of hypercapnia on the blood-brain barrier to sucrose in the rabbit. Yale J. Biol. Med. 42:241-47.

Carvalho, M. R. 1999. Hidrogeologia do maciço vulcanico de Água de Pau/Fogo (Sao Miguel e Açores). Lisboa: Universidade de Lisboa.

Clemedson, C. -. J., H. Hartelius, and G. Holmberg. 1958. The influence of carbon dioxide inhalation on the cerebral vascular permeability to trypan blue ("the blood-brain barrier”). Acta Pathol. Microbiol. Scand. 42:137-49. doi:10.1111/j.1699-0463.1958.tb03178.x.

Coakley, R. J., C. Taggart, C. Greene, N. G. Mcelvaney, and S. J. O. Neill. 2002. Ambient pco $_{2}$ modulates intracellular ph, intracellular oxidant generation, and interleukin-8 secretion in human neutrophils abstract: although neutrophils are a critical component of the inflammatory process. Their 71:603-10.

Colombo, E., and C. Farina. 2016. Astrocytes: Key regulators of neuroinflammation. Trends Immunol. 37 (9):608-20. doi:10.1016/j.it.2016.06.006.

Cordiglieri, C., and C. Farina. 2010. Astrocytes exert and control immune responses in the brain. Curr. Immunol. Rev. 6:150-59. doi:10.2174/157339510791823655. 
Cutler, R. W. P., and C. F. Barlow. 1966. The effect of hypercapnia on brain permeability to protein. Arch. Neurol. 14 (1):54-63. doi:10.1001/archneur.1966.00470070058007.

Durand, M., C. Florkowski, P. George, T. Walmsley, P. Weinstein, and J. Cole. 2004. Elevated trace element output in urine following acute volcanic gas exposure. J. Volcanol. Geothermal Res. 134 (1-2):139-48. doi:10.1016/j.jvolgeores. 2004.01.007.

Durand, M., and J. Grattan. 2001. Effects of volcanic air pollution on health. The Lancet 357 (9251):2001. doi:10.1016/S0140-6736(00)03586-8.

Eddleston, M., and L. Mucke. 1993. Molecular profile of reactive astrocytes-implications for their role in neurologic disease. Neuroscience 54:15-36. doi:10.1016/0306-4522(93)90380-X.

Farina, C., F. Aloisi, and E. Meinl. 2007. Astrocytes are active players in cerebral innate immunity. Trends Immunol. 28 (3):138-45. doi:10.1016/j.it.2007.01.005.

Farina, M., D. S. Avila, J. B. T. Da Rocha, and M. Aschner. 2013. Metals, oxidative stress and neurodegeneration: a focus on iron, manganese and mercury. Neurochem. Int. 62 (5):575-94. doi:10.1016/j.neuint.2012.12.006.

Faulkner, J. R., J. E. Herrmann, M. J. Woo, K. E. Tansey, N. B. Doan, and M. V. Sofroniew. 2004. Reactive astrocytes protect tissue and preserve function after spinal cord injury. J. Neurosci. 24 (9):2143-55. doi:10.1523/JNEUROSCI.354703.2004 .

Ferreira, A. F., P. V. Garcia, R. Camarinho, and A. D. S. Rodrigues. 2015. Volcanogenic pollution and testicular damage in wild mice. Chemosphere 132:135-41. doi:10.1016/j.chemosphere.2015.03.017.

Ferreira, T., J. L. Gaspar, F. Viveiros, M. Marcos, C. Faria, and F. Sousa. 2005. Monitoring of fumarole discharge and $\mathrm{CO}_{2}$ soil degassing in the Azores: Contribution to volcanic surveillance and public health risk assessment. Ann. Geoph. 48:787-96.

Forsyth, D. 2001. Extrapolation of laboratory tests to field populations. In Ecotoxicology of wild mammals, ed. R. Shore and B. Rattner, 577-634. Chichester: John Wiley and Sons.

Genc, S., Z. Zadeoglulari, S. H. Fuss, and K. Genc. 2012. The adverse effects of air pollution on the nervous system. J. Toxicol. 2012: 782462.

Görg, B., M. Wettstein, S. Metzger, F. Schliess, and D. Häussinger. 2005. LPS-induced tyrosine nitration of hepatic glutamine synthetase. Hepatology 42 (2):499-499. doi:10.1002/hep.20820.

Groves-Kirkby, C. J., A. R. Denman, A. C. Woolridge, P. S. Phillips, and C. Phillips. 2006. Environmental radon gas and degenerative conditions. Paper presented at the Second European IRPA Congress on Radiation Protection, Paris, France, May 15-19.

Gustin, M. S., S. E. Lindberg, and P. J. Weisberg. 2008. An update on the natural sources and sinks of atmospheric mercury. Appl. Geochem. 23 (3):482-93. doi:10.1016/j. apgeochem.2007.12.010.

Hansell, A., and C. Oppenheimer. 2004. Health hazards from volcanic gases: A systematic literature review. Archives of
Environmental Health: An International Journal 59 (12):628-39. doi:10.1080/00039890409602947.

Hansell, A. L., C. J. Horwell, and C. Oppenheimer. 2006. The health hazards of volcanoes and geothermal areas. Occup. Environ. Med. 63 (2):149-56. doi:10.1136/oem.2005.022459.

Harry, G. J., and C. L. D'Hellencourt. 2003. Dentate gyrus: Alterations that occur with hippocampal injury. NeuroToxicol. 24 (3):343-56. doi:10.1016/S0161-813X(03)00039-1.

Hedden, T., and J. D. E. Gabrieli. 2004. Insights into the ageing mind: A view from cognitive neuroscience. Nat. Rev. Neurosci. 5 (2):87-96. doi:10.1038/nrn1323.

Holmberg, K., and C. Small. 2015. People and volcanoes: How many and how close? Paper presented at Fall Meeting of the American Geophysical Union, San Francisco, United States, December 14-18.

Horwell, C. J. 2007. Grain-size analysis of volcanic ash for the rapid assessment of respiratory health hazard. J. Environ. Monitor. 9 (10):1107-15. doi:10.1039/b710583p.

Hostenbach, S., M. Cambron, M. D’haeseleer, R. Kooijman, and J. De Keyser. 2014. Astrocyte loss and astrogliosis in neuroinflammatory disorders. Neurosci. Lett. 565:39-41. doi:10.1016/j.neulet.2013.10.012.

Huang, S., C. T. Farrar, G. Dai, S. J. Kwon, A. A. Bogdanov, B. R. Rosen, and Y. R. Kim. 2013. Dynamic monitoring of blood-brain barrier integrity using water exchange index (WEI) during mannitol and $\mathrm{CO}_{2}$ challenges in mouse brain. NMR Biomed. 26 (4):376-85. doi:10.1002/nbm.2871.

Ishigami, A., Y. Kikuchi, S. Iwasawa, Y. Nishiwaki, T. Takebayashi, S. Tanaka, and K. Omae. 2008. Volcanic sulfur dioxide and acute respiratory symptoms on Miyakejima Island. Occup. Environ. Med. 65 (10):701-07. doi:10.1136/oem.2007.033456.

Iwasawa, S., M. Nakano, T. Tsuboi, T. Kochi, S. Tanaka, T. Katsunuma, A. Morikawa, and K. Omae. 2015. Effects of sulfur dioxide on the respiratory system of Miyakejima child residents 6 years after returning to the island. Int. Arch. Occup. Environ. Health 88 (8):1111-18. doi:10.1007/s00420-015-1037-y.

Jayaraj, R. L., E. A. Rodriguez, Y. Wang, and M. L. Block. 2017. Outdoor ambient air pollution and neurodegenerative diseases: The neuroinflammation hypothesis. Curr. Environ. Health Rep. 4:166-79.

Kazazoglou, T., E. Fleischer-Lambropoulos, T. Geladopoulos, S. Kentroti, C. Stefanis, and A. Vernadakis. 1996. Differential responsiveness of late passage C-6 glial cells and advanced passages of astrocytes derived from aged mouse cerebral hemispheres to cytokines and growth factor: Glutamine synthetase activity. Neurochem. Res. 21 (5):609-14. https://link.springer. com/article/10.1007/BF02527760.

Kempuraj, D., R. Thangavel, P. A. Natteru, G. P. Selvakumar, D. Saeed, H. Zahoor, S. Zaheer, S. S. Iyer, and A. Zaheer. 2016. Neuroinflammation induces neurodegeneration. J. Neurol. Neurosurg. Spine 1:1003. http://www.ncbi.nlm. nih.gov/pubmed/28127589.

Kristbjornsdottir, A., and V. Rafnsson. 2012. Incidence of cancer among residents of high temperature geothermal areas in Iceland: A census based study 1981 to 2010. Environ. Health 11 (1):1-12. doi:10.1186/1476-069X-11-73. 
Lana, D., F. Ugolini, D. Nosi, G. L. Wenk, and M. G. Giovannini. 2017. Alterations in the interplay between neurons, astrocytes and microglia in the rat dentate gyrus in experimental models of neurodegeneration. Front. Aging Neurosci. 9:1-17. doi:10. 3389/fnagi.2017.00296.

Li, B., H. Yamamori, Y. Tatebayashi, B. Shafit-Zagardo, H. Tanimukai, S. Chen, K. Iqbal, and I. Grundke-Iqbal. 2008. Failure of neuronal maturation in Alzheimer disease dentate gyrus. J. Neuropathol. Exp. Neurol. 67 (1):78-84. doi:10.1097/nen.0b013e318160c5db.

Linhares, D., P. Ventura Garcia, F. Viveiros, T. Ferreira, and A. D. S. Rodrigues. 2015. Air pollution by hydrothermal volcanism and human pulmonary function. Biomed. Res. Int. 2015:326794. doi:10.1155/2015/326794.

Linhares, D. P. S., P. V. Garcia, L. Amaral, T. Ferreira, J. A. Cury, W. Vieira, and A. D. S. Rodrigues. 2016. Sensitivity of two biomarkers for biomonitoring exposure to fluoride in children and women: A study in a volcanic area. Chemosphere 155:614-20. doi:10.1016/j.chemosphere.2016.04.092.

Liu, B., H. M. Gao, and J. S. Hong. 2003. Parkinson's disease and exposure to infectious agents and pesticides and the occurrence of brain injuries: Role of neuroinflammation. Environ. Health Perspect. 111 (8):1065-73. doi:10.1289/ehp.6361.

Maragakis, N. J., and J. D. Rothstein. 2006. Mechanisms of disease: Astrocytes in neurodegenerative disease. Nat. Clin. Pract. Neurol. 2:679-89.

Marxreiter, F., M. Regensburger, and J. Winkler. 2013. Adult neurogenesis in Parkinson's disease. Cell. Mol. Life Sci. 70:459-73.

McBean, G. J., K. B. Doorty, K. F. Tipton, and H. Kollegger. 1995. Alteration in the glial cell metabolism of glutamate by kainate and n-methyl-d-aspartate. Toxicon 33 (4):569-76. doi:10.1016/0041-0101(94)00187-D.

Miñana, M.-D., E. A. Kosenko, G. Marcaida, C. Hermenegildo, C. Montoliu, S. Grisolía, and V. Felipo. 1997. Modulation of glutamine synthesis in cultured astrocytes by nitric oxide. Cell. Mol. Neurobiol. 17 (4):433-45. https://www.researchgate.net/publi cation/226564845.

Muse, E. D., H. Jurevics, A. D. Toews, G. K. Matsushima, and P. Morell. 2001. Parameters related to lipid metabolism as markers of myelination in mouse brain. J. Neurochem. 76 (1):77-86. doi:10.1046/j.1471-4159.2001.00015.x.

Myer, D. J., G. G. Gurkoff, S. M. Lee, D. A. Hovda, and M. V. Sofroniew. 2006. Essential protective roles of reactive astrocytes in traumatic brain injury. Brain 129 (10):2761-72. doi:10.1093/brain/awl165.

Nagarkatti, M., P. S. Nagarkatti, and A. Brooks. 1996. Effect of radon on the immune system: Alterations in the cellularity and functions of $\mathrm{t}$ cells in lymphoid organs of mouse. J. Toxicol. Environ. Health 47 (6):535-52. doi:10.1080/009841096161528.

Nagele, R. G., J. Wegiel, V. Venkataraman, H. Imaki, K.C. Wang, and J. Wegiel. 2004. Contribution of glial cells to the development of amyloid plaques in Alzheimer's disease. Neurobiol. Aging 25 (5):663-74. doi:10.1016/j. neurobiolaging.2004.01.007.

Navarro-Sempere, A., Y. Segovia, A. Rodrigues, P. Garcia, R. Camarinho, and M. Garcia. 2020. First record on mercury accumulation in mice brain living in active volcanic environments: A cytochemical approach. Environ. Geochem. Health. doi:10.1007/s10653-020-00690-4.

Niranjan, R. 2014. The role of inflammatory and oxidative stress mechanisms in the pathogenesis of parkinson's disease: Focus on astrocytes. Mol. Neurobiol. 49 (1):28-38. doi:10.1007/s12035-013-8483-x.

Norozian, F. M., M. Leoncio, D. Torbati, K. Meyer, A. Raszynski, B. R. Totapally, and K. Meyer. 2011. Therapeutic hypercapnia enhances the inflammatory response to endotoxin in the lung of spontaneously breathing rats. Crit. Care Med. 39 (6):1400-06. doi:10.1097/CCM.0b013e31820ee1f2.

Pakulski, C. 1998. The influence of acute hypercapnia on the permeability of the blood-brain barrier for gentamycin under conditions of general anesthesia in rabbits. Ann. Acad. Med. Stetin. 44:285-96.

Pałasz, A., Y. Segovia, R. Skowronek, and J. J. Worthington. 2019. Molecular neurochemistry of the lanthanides. Synapse 73:syn.22119. doi:10.1002/syn.22119.

Peebles, K. C., A. M. Richards, L. Celi, K. McGrattan, C. J. Murrell, and P. N. Ainslie. 2008. Human cerebral arteriovenous vasoactive exchange during alterations in arterial blood gases. J. Appl. Physiol. 105 (4):1060-68. https://www.physiology.org/doi/10. 1152/japplphysiol.90613.2008.

Pekny, M., U. Wilhelmsson, and M. Pekna. 2014. The dual role of astrocyte activation and reactive gliosis. Neurosci. Lett. 565:30-38. doi:10.1016/j.neulet.2013.12.071.

Quere, J., and J. Vincent. 1989. Détermination de l'âge chez le mulot gris (Apodemus sylvaticus L., 1758) par la pesée des cristallins. Mammalia 53 (2). doi:10.1515/mamm.1989.53.2. 287.

Rodrigues, A. S., M. S. C. Arruda, and P. V. Garcia. 2012. Evidence of DNA damage in humans inhabiting a volcanically active environment: A useful tool for biomonitoring. Environ. Int. 49:51-56. doi:10.1016/j.envint.2012.08.008.

Rodríguez, J. J., V. C. Jones, M. Tabuchi, S. M. Allan, E. M. Knight, F. M. LaFerla, S. Oddo, A. Verkhratsky, and K. Gwinn. 2008. Impaired adult neurogenesis in the dentate gyrus of a triple transgenic mouse model of Alzheimer's disease. PLOS ONE 3 (8):e2935. doi:10.1371/journal.pone.0002935.

Rose, C. F., A. Verkhratsky, and V. Parpura. 2013. Astrocyte glutamine synthetase: Pivotal in health and disease. Biochem. Soc. Trans. 41 (6):1518-24. /biochemsoctrans/article/41/6/1518/ 68113/Astrocyte-glutamine-synthetase-pivotal-in-health.

Rose, C. R., L. Felix, A. Zeug, D. Dietrich, A. Reiner, and C. Henneberger. 2018. Astroglial glutamate signaling and uptake in the hippocampus. Front. Mol. Neurosci. 10:451. /pmc/articles/PMC5776105/?report=abstract.

Russo, M. V., and D. B. McGavern. 2015. Immune surveillance of the CNS following infection and injury. Trends Immunol. 36 (10):637-50. doi:10.1016/j.it.2015.08.002.

Russo, M. V., and D. B. McGavern. 2016. Inflammatory neuroprotection following traumatic brain injury. Science 353 (6301):783-85. doi:10.1126/science.aaf6260.

Selin, N. E. 2009. Global biogeochemical cycling of mercury: A review. Annu. Rev. Environ. Resour. 34:43-63. http://www. annualreviews.org/doi/10.1146/annurev.environ.051308. 084314. 
Silva, C., T. Ferreira, F. Viveiros, and P. Allard. 2015. Soil Radon $\left({ }^{222} \mathrm{Rn}\right)$ monitoring at Furnas volcano (São Miguel, Azores): Applications and challenges. Eur. Phys. J. Spec. Top. 224:659-86.

Sitcheran, R., P. Gupta, P. B. Fisher, and A. S. Baldwin. 2005. Positive and negative regulation of EAAT2 by NF-KB: A Role for $\mathrm{N}-\mathrm{Myc}$ in $\mathrm{TNF}$-controlled repression. The EMBO Journal 24 (3):510-20. http://emboj.embopress.org/ cgi/doi/10.1038/sj.emboj.7600555.

Small, C., and T. Naumann. 2001. The global distribution of human population and recent volcanism. Environ. Hazards 3 (3):93-109. doi:10.3763/ehaz.2001.0309.

Small, S. A., W. Y. Tsai, R. Delapaz, R. Mayeux, and Y. Stern. 2002. Imaging hippocampal function across the human life span: Is memory decline normal or not? Ann. Neurol. 51 (3):290-95. doi:10.1002/ana.10105.

Sofroniew, M. V. 2009. Molecular dissection of reactive astrogliosis and glial scar formation. Trends Neurosci. 32 (12):638-47. doi:10.1016/j.tins.2009.08.002.

Sofroniew, M. V., and H. V. Vinters. 2010. Astrocytes: Biology and pathology. Acta Neuropathol. 119:7-35.

Son, H., S. Kim, D. Hyuk Jung, J. H. Baek, D. H. Lee, G. S. Roh, S. S. Kang, G. J. Cho, W. S. Choi, D. K. Lee, et al. 2019. Insufficient glutamine synthetase activity during synaptogenesis causes spatial memory impairment in adult mice. Sci. Rep. 9 (1):1-9. www.nature.com/scientificreports/

Song, W., A. Patel, H. Y. Qureshi, D. Han, H. M. Schipper, and H. K. Paudel. 2009. The parkinson disease-associated A30P mutation stabilizes $\alpha$-synuclein against proteasomal degradation triggered by heme oxygenase-1 over-expression in human neuroblastoma cells. J. Neurochem. 110 (2):719-33. doi:10.1111/j.1471-4159.2009.06165.x.

Steward, O., M. S. Kelley, and E. R. Torre. 1993. The process of reinnervation in the dentate gyrus of adult rats: Temporal relationship between changes in the levels of glial fibrillary acidic protein (GFAP) and GFAP mRNA in reactive astrocytes. Exp. Neurol. 124 (2):167-83. doi:10.1006/exnr.1993.1187.

Suárez, I., G. Bodega, and B. Fernández. 2002. Glutamine synthetase in brain: Effect of ammonia. Neurochem. Int. 41 (2-3):123-42. doi:10.1016/S0197-0186(02)00033-5.

Tam, E., R. Miike, S. Labrenz, A. J. Sutton, T. Elias, J. Davis, Y.L. Chen, K. Tantisira, D. Dockery, and E. Avol. 2016. Volcanic air pollution over the Island of Hawaii: Emissions, dispersal, and composition. Association with respiratory symptoms and lung function in Hawaii Island school children. Environ. Int. 92-93:543-52. doi:10.1016/j. envint.2016.03.025.

Tarkowski, E., N. Andreasen, A. Tarkowski, and K. Blennow. 2003. Intrathecal inflammation precedes development of Alzheimer's disease. J. Neurol. Neurosurg. Psychiatr. 74 (9):1200-05. doi:10.1136/jnnp.74.9.1200.

Tersago, K., W. De Coen, J. Scheirs, K. Vermeulen, R. Blust, D. Van Bockstaele, and R. Verhagen. 2004. Immunotoxicology in wood mice along a heavy metal pollution gradient. Environ. Pollut. $132 \quad$ (3):385-94. doi:10.1016/j.envpol.2004. 05.029.
Thiel, V. E., and K. L. Audus. 2001. Nitric oxide and bloodbrain barrier integrity. In Antioxidants and Redox Signal, 3 :273-78. Mary Ann Liebert Inc. https://www.liebertpub. com/doi/abs/10.1089/152308601300185223.

Tiffany-Castiglioni, E., and Y. Qian. 2001. Astroglia as metal depots: Molecular mechanisms for metal accumulation, storage and release. Neurotoxicology 22 (5):577-92. doi:10.1016/S0161-813X(01)00050-X.

Tong, J., L. Qin, Y. Cao, J. Li, J. Zhang, J. Nie, and Y. An. 2012. Environmental radon exposure and childhood leukemia. Journal of Toxicology and Environmental Health, Part B 15 (5):332-47. doi:10.1080/10937404.2012.689555.

Tracy, B. L. D., D. Krewski, J. M. Chen, J. M. Zielinski, K. P. Brand, and D. Meyerhof. 2006. Assessment and management of residential radon health risks: A report from the health Canada radon workshop. Journal of Toxicology and Environmental Health, Part A 69 (7-8):735-58. doi:10.1080/15287390500261281.

Viveiros, F., C. Cardellini, T. Ferreira, and C. Silva. 2012. Contribution of $\mathrm{CO}_{2}$ emitted to the atmosphere by diffuse degassing from volcanoes: The Furnas volcano case study. Int. J. Global Warm. 4:287-304. doi:10.1504/IJGW.2012.049 444.

Viveiros, F., C. Cardellini, T. Ferreira, S. Caliro, G. Chiodini, and C. Silva. 2010. Soil $\mathrm{CO}_{2}$ emissions at Furnas volcano, São Miguel Island, Azores archipelago: Volcano monitoring perspectives, geomorphologic studies, and land use planning application. J. Geophys. Res. 115 (B12):B12208. doi:10.1029/2010JB007555.

Walsh, T. J., and D. F. Emerich. 1988. The hippocampus as a common target of neurotoxic agents. Toxicology 49 (1):137-40. https://pubmed.ncbi.nlm.nih.gov/3287689/.

Wang, Z., O. Pekarskaya, M. Bencheikh, W. Chao, H. A. Gelbard, A. Ghorpade, J. D. Rothstein, and D. J. Volsky. 2003. Reduced expression of glutamate transporter EAAT2 and impaired glutamate transport in human primary astrocytes exposed to HIV-1 or Gp120. Virology 312 (1):60-73. doi:10.1016/S0042-6822(03)00181-8.

Weinstein, P., C. J. Horwell, and A. Cook. (2005) 2013. Volcanic emissions and health. In Essentials of Medical Geology: impacts of the natural environment on public health, 203-226. Amsterdam: Elsevier Academic Press.

WHO. 2003. Hydrogen sulfide : Human health aspects. In Concise international chemical assessment document 47: Arsine: Human health aspects. Geneva: World Health Organization.

Zhang, D., X. Hu, L. Qian, J. P. O'Callaghan, and J.-S. Hong. 2010. Astrogliosis in CNS pathologies: Is there a role for microglia? Mol. Neurobiol. 41 (2-3):232-41. doi:10.1007/s12035-010-8098-4.

Zheng, C., X.-W. Zhou, and J.-Z. Wang. 2016. The dual roles of cytokines in Alzheimer's disease: Update on interleukins, TNF$\alpha$, TGF- $\beta$ and IFN- $\gamma$. Transl. Neurodegener 5 (1):7. https://link. springer.com/articles/10.1186/s40035-016-0054-4.

Zou, J., Y.-X. Wang, -F.-F. Dou, H.-Z. Lü, Z.-W. Ma, P.-H. Lu, and X.-M. Xu. 2010. Glutamine synthetase down-regulation reduces astrocyte protection against glutamate excitotoxicity to neurons. Neurochem. Int. 56 (4):577-84. doi:10.1016/j.neuint. 2009.12.021. 